\title{
Dividend Practices in Listed Companies: Study on the Manufacturing Sector of Bangladesh
}

\begin{abstract}
The dividend model of the listed manufacturing firms and the organizational policies related to dividend decisions are analyzed to reveal the contemporary state of the payout pattern in the capital market of Bangladesh. This study exhibits the settings of dividend disbursement in association with the diverse aspects of the firm such as industry segment of the firm, the age of the firms, size, leverage, risk, and earnings.
\end{abstract}

Keywords: dividend, EPS, Signaling Theory, MM model.

Siekiant atskleisti dabartinį Bangladešo kapitalo rinkos dividendų išmokẻjimo modelio scenarijų, analizuojami listinguojamų gamybos įmonių dividendų modeliai ir dividendų valdymo politikos. Tyrimas atskleidé, kad dividendų išmokejjimo modelis susijęs su skirtingomis ịmonès charakteristikomis, tokiomis kaip įmonès pramonès segmentas, ̨̣monés amžius, dydis, svertas, rizika ir pajamos.

Raktiniai žodžiai: dividendai, pelnas vienai akcijai (EPS), signalizavimo teorija, Modigliani-Millerio modelis.

\section{Introduction}

Payout strategy has been always a popular area of study for its association with the firms investing and financing decision making and its influence on shareholder value generation. Even though numerous researches have been carried out to identify potential reasons of dividend payout, no uniform explanation has been sustained (Baker, Powell and Veit, 2002) That dynamism of dividend pattern makes payout strategy as one of the most contentious subject and explored field of corporate finance but even now, the dividend dilemma exists. Regardless of its complexity, formulating the most suitable payout policy is considered as vital as well as an equally challenging task. However, the key variables are considerably uncomplicated to recognize but the connections amongst these variables are multifaceted and no straightforward solution exists (Ross, 2009).

Several hypotheses have been proposed to give an explanation regarding the process of dividend decision making and the value relevance of the dividend payment for the shareholders as well as the firms. However, there are three different states of belief in regard to the value relevance of dividend.

\footnotetext{
Mohammad Shahidul ISLAM - Ph.D., associate professor, finance, Department of Business Administration, BGMEA University of Fashion and Technology (BUFT), Nishatnagar, Turag, Dhaka-1230, Bangladesh. Phone: 8801758-075844. E-mail: mohammadshahidul.islam@buft.edu.bd
}

ATM ADNAN - M.Sc., MBA, assistant professor, accounting and finance, Department of Business Administration, BGMEA University of Fashion and Technology (BUFT), Nishatnagar, Turag, Dhaka-1230, Bangladesh. Phone: 8801843770138. E-mail: atmadnan@buft.edu.bd 
The pro-dividend group believes that the dividend payout is affirmatively associated with the value of the firm. There are prominent studies in favor of the position (Lintner, 1962; Frankfurter and Lane, 1992; Ball et al., 1979; Asquith and Mullins, 1983). These studies tried to prove empirically that dividend can act an instrument of financial signaling to the external stakeholders of the firms exhibiting the growth potentiality and steadiness of the firm (Bernhardt, Douglas, Robertson, 2005). Another argument in support of this position relates to agency theory. It states that by disbursing an adequate sum of dividend, a corporation can avoid the agency issue. The dividend disbursements are cooperative to retain corporations in the market, where the conflict of interest between managers and agents are kept at low cost (Rozeff, 1982; La Porta et al., 2000). A residual earning is beneficial for the corporation to allow it between investors as dividends resulting in the reduction of the chance of these funds being whacked on insolvent ventures (Jensen, 1986).

Contrary to the pro-dividend position is the dividend-averse position, which believes that more dividends will eventually decrease the value of the firm. The underlying reason is that entities' investment opportunities have a substantial influence on its dividend disbursement strategy; the entities with fewer investment opportunities has a larger amount of residual earnings to dispense as dividends. However greater dividend and lower investment opportunities also convey lower growth potentiality for the firms which ultimately results in a lower dividend. Due to the greater investment prospects, companies move from higher dividends to lower dividend pattern. So, there is a pessimistic association exists between the profit disbursement and investment opportunities (Smith Jr., Watts, 1992; Glen, Karmokolias, Miller, Shah, 1995; Fama, French, 2002).

The dividend neutral position originally supported by the prominent research work by (Miller, Modigliani, 1961) claims that dividend has nothing to do with the value of the firm assuming there is no applicable tax, transaction costs and any sort of market imperfections (Richardson, Sefcik, Thompson, 1986). Since the empirical findings of (Miller, Modigliani, 1961) the dividend research has gained further momentum on investigating the pattern of dividend policy, the significance of dividend policy and the determinants of dividend decision (DeAngelo, DeAngelo, 2006).

The contradictory hypothesis associated with the dividend policy makes the dividend strategy one of the most critical and puzzled research topics in the field of corporate finance as it intends to decrease the disagreement of interest between investors and managers. Although significant modification has been brought in to dividend policy generation by several empirical studies in the last twenty years, the issue of uniform and scaled dividend policy are still not settled (Baker, Weigand, 2015; Bhattacharyya, 2007). The changes are not only limited to managers keenness to disburse but also to national guidelines, macroeconomic trends, recessions, and financial turbulences (Denis, Osobov, 2008; Frankfurter, Wood Jr., 2002; Gugler, Yurtoglu, 2003).

Therefore, several concepts and philosophies have been argued to examine questions such as what elements stimulate payout policy, explanations for 
disbursing residual profit, patterns of dividend, and the consequences of dividend disbursements on firms and investors wealth generation.

The subject of payout strategy is vital for numerous reasons. Initially, the corporation can utilize the dividend as a signaling tool for investors and other stakeholders to portray the growth potential and stability of the firms. Moreover, dividend works as a substantial part in a corporation's capital construction (Frank, Goyal, 2003; Aggarwal, Kyaw, 2010) as the residual dividend argues, firms only disburse profit in case of the absence of the profitable business opportunities (Baker, Smith, 2006; Smith, 2009). However, companies generally unlike to reduce the dividend payments as numerous studies found a positive association between stock value and dividend disbursement (Hashemijoo, Mahdavi-Ardekani, Younesi, 2012; Hussainey et al., 2011). Nevertheless, it can be interpreted that the features defining the dividend strategy are diverse.

The dividend strategy variables have been intensively approached and studied in developed economies by prominent researchers such as (Miller, Modigliani, 1961, Fama, Babiak, 1968; Black, Scholes, 1973; Lease et al., 1999), etc., however, in the case of developing nations, very negligible amount of researches have been approached in the field of dividend policy factors and pattern of dividend decisions. The situation is even worse in the case of Bangladesh where hardly any investigative studies related to the pattern of dividend policy have been performed. So, there is a call for investigating the pattern of dividend policy of Bangladeshi firms which will eventually facilitate the managers to decide on the investment and payout decisions.

This study aims to discover dividend disbursement exercise in the listed manufacturing segment in Bangladesh. The dividend structure of listed manufacturing companies and the management' policies related to dividend decisions are analyzed to reveal the current picture of payout pattern in the capital market of Bangladesh. This research exhibits the structure of dividend disbursement in association with the various features of the firm such as industry segment of the company, the age of the company, size, leverage, risk, earnings, etc. The dividend practices of the firms are collected through the questionnaire survey of the selected manufacturing firms.

The empirical outcomes of the study disclose that the miscellaneous sector delivers the maximum dividend. The study also exhibited that the DPS, EPS, MPS of the large size corporation is superior than that of small and medium-size firms moreover the dividend disbursement of the older firms is higher than that of newly listed firms. Additionally, the maximum dividends are seen in case of moderately leveraged firms. The survey outcomes also exposed that most of the investors and companies prefer the cash dividend due to less risk factor and high liquidity which is similar to the findings of research findings such as (Graham, Kumar, 2006; Lang, Litzenberger, 1989; Shefrin, Statman, 1984).

The assessment of payout strategy in developing markets has not been developed as it has been intensely researched in developed economies. However, the influential factors that might significantly affect the dividend pattern and decision 
are equally present in the developing markets. This research attempts to deliver a comprehensive analysis of payout pattern and decision determinants in the manufacturing sector of Bangladesh, a developing market that has been insignificantly examined to date. Moreover, developing capital market holds quite a few comparable attributes so, to a considerable level, dividend pattern in Bangladesh possibly will convey some imperative similarities with other developing capital markets. Therefore, the discoveries of this kind of thorough country-specific case study could build the foundation of forthcoming relative studies into different developing capital markets.

This study is organized as follows, the introduction of the study with the objective and significance is followed by the in-depth study of the prominent literature have been conducted in developed and developing market context. The third section portrays the methodology of the research which explains the sample size, data source, scope, and statistical techniques of the study. It also includes several factors of dividend policy used in prior studies. Next segment shows the result of the experiment. Last but not the least part exhibits the conclusive remarks extracted from the findings of the research.

\section{Literature review}

The opening point in the practical research on payout policy was the (Lintner, 1956) model, which validates the corporate dividend pattern as a fractional adjustment model. J. Lintner (1956) performed his investigation on US-based companies in the mid-50s found that current payout decision is predominantly depending on the current earnings and partly on the basis of prior period's dividend. Later on, the face of significant controversies regarding the dividend policy and dispersions in empirical findings $\mathrm{E}$. F. Fama and H. Babiak (1968) reexamined the model of Lintner on the payout data of major North American manufacturing corporations for 20 years period came up with the similar outcomes. E. F. Fama and H. Babiak (1968) has also argued that corporations might try to enhance their dividend amount only when they exhibit a growth potentiality and stability in the dividend. They also claimed that Lintner's dividend model is competent enough in clarifying the dividend pattern of particular firms.

N. J. Dhameja (1976) demonstrated that there is statistically insignificant connection between profit disbursement and industry type. Investment and growth opportunities are proved to be considerably and conversely connected to dividend disbursement. R. R. Pettit (1977) investigated the clientele effect of payout found that retired investors and pension fund holders have a tendency to desire cash return and thus demand the firm to disburse a large percentage of its revenue. On the other hand, contrary to this position investors in their highest earning years prefer the reinvestment of earnings and low cash disbursement. M. S. Rozeff (1982) exhibited a diverse association between the payout pattern and leverage of the firm. The study argued that leverage and dividend payment are negatively correlated with each other. The potential reason for this could be the debt covenants. The paper also indicated that corporations with large financial leverage incline 
to hold low dividend yield in order to decrease the transaction costs related to external financing. R. Bhat and I. Pandey (1994) exhibited that disbursement of dividend depends majorly on present and projected revenue along with the previous dividend practices. They also found that liquidity position isn't a major factor in payout strategy. M. C. Collins et al. (1996) found that the contribution of insiders in the selection of the payout strategy of a corporation. The findings specified that firms Dividend payout ratio (DPR) is negatively associated with its prior and forthcoming anticipated growth in earning, its systematic risk level and the ownership percentage of insiders. They also addressed that regulatory framework performed a significant part in the assessment of the depth of association involving insider ownership and a DPR in the case of utility firms than that of financial firms. P. Mohanty (1999) exhibited that regular dividend disbursement being the primary characteristics in most of the selected firms even though there has been a steady drop in the dividend payout ratio. The researcher also exhibited that payout ratios are more inflated compared to the actual effective rates of dividend as characterized by dividend yield. In case of steadiness in dividend disbursement, the research discovered high steadiness in dividend yields but less consistency in terms of dividend payouts rates.

R. La Porta et al. (2000) argued that corporations in countries with higher shareholder protection make superior dividend disbursement compared to the corporations in low shareholders protection region. In addition to that, nations with higher legal safeguard, high growth corporations experience smaller dividend disbursement percentage. This result is consistent to the 'outcome agency model' where shareholders are able to apply their legal authority to influence dividends payout in low growth scenario. Therefore, the findings specified that exclusive of pressure to management there are no other strong enticement for the management to give high payout as a representative of firm's strength and growth. Additionally, it is not evident that nations with less shareholders security, management will willingly disburse superior dividends as well as to frequent market monitoring.

V. Aivazian, L. Booth and S. Cleary (2001) found that a corporation's payout policy is influenced by earnings, size, debt structure, risk exposure, visibility and opportunities of growth. H. Ho (2003) performed a study on payout strategies in Japan and Australia. The outcome strongly established the signaling, agency, and transactions cost theories of dividend policy. The study also exhibited that among the regressed variable in determining the most significant factor of dividend policy, size for Australia and Liquidity for Japan became the most significant factor. The competing industry segment also found to be significant in case of both Australia and Japan for determining payout policy. K. Gugler and B. B. Yurtoglu (2003) stated that state owned corporations are described by dividend smoothening, excessive dividend disbursement and high unwillingness to curtail dividends whereas private family dominated corporations are not found to be associated to dividend smoothening, experience a minimal payout and are less unwilling to curtail payout. According to the researcher, this result is more applicable in case of the firms with excellent growth projection 
(high Research \& Development expenditures). However, firms with lower growth potentiality having nominal research and development investments, the indented disbursement percentage tends to be a lot higher regardless of who regulates the firms. J. Kumar (2003) in his study on Indian manufacturing firms explore the likely connection between corporate governance, ownership structure and corporation's dividend strategy and revealed a positive relation exists between payout and profit pattern. Debt ratio was found to be negatively correlated, while investment opportunities are positively correlated with the dividend policy.

Seminal studies (Aivazian et al., 2003; Denis, Osobov, 2008) discovered that positive association exists involving the firm size and the payout. Large firms tend to give higher dividend as they have got easy access to the fund sources compared to less accessibility of smaller firms to the funds thus these smaller firms tend to be more dependent on the internal sources of fund which is the retained earnings or undistributed profits. This finding is also similar to the results of other studies such as (AlTwaijry, 2007) and (Abor, Bokpin, 2010).

A. Brav et al. (2005) argued that the payout level depends on investment opportunities and liquidity. A rise in dividend is only considered after the investment opportunities are evaluated and liquidity requirements are fulfilled. They revealed that managers convey a positive interest to evade dividend reduction except in an unexpected situation. They also identified that stable growth in revenues and demand from institutional shareholders are the two main reasons for the dividend reluctant firms/managers to start dividend disbursement. They pointed out negligible existence of signaling theories neither they found proof that managers apply payout policy to attract specific investment offers. The study also pointed out that tax rate is not significant feature in determining dividend strategy but to some extent seemed to be important for a small number of firms. S. Kania and F. Bacon (2005) used the OLS method to analyze the financial date of more than ten thousand publicly traded firms with a view to identify the influential firm aspect deciding payout pattern discover that dividend yield is considerably shaped by the ROE (return on equity), growth of revenue, risk factor expressed in beta, current asset position (liquidity), ownership structure, and investment opportunities in capital asset. In the context of the Arab region, H. A. Nizar Al-Malkawi (2007) studied the factors of corporate payout strategy in Jordan in the late ' 90 s. He argued that Asset holdings (size), year of operation (age) and earning capability (Profitability) are the key factors that outline the corporation's payout strategy in Jordan. The findings are significantly uniform with the agency cost theory and pecking order theory. Moreover, H. A. Nizar Al-Malkawi (2007) empirically justified that highly levered firms tend to disburse less dividend which is parallel to the result of R. La Porta et al. (2000), however, contrary to the findings of S. Kania and F. Bacon (2005) which found strong positive bonding between debt to equity and dividend payout. S. Naeem and M. Nasr (2007) identified another dimension of the dividend policy which is the ownership of the firms. They showed that government-owned and controlled corporations try to maintain a constant pattern of dividend payout whereas family 
owned controlled corporations are inconsistent in their dividend payout. The findings of the research are also similar to the result of C. W. Smith Jr. and R. L. Watts (1992) on the Chinese context. They also discovered that the internal ownership structure also performs a noteworthy part in payout policy. A. Parua and A. Gupta (2009) justified that recent profitability of the firms, trends of contemporary and prior payout, liquidity position and earning potentiality were the key factors of payout strategy whereas, determinants like investment opportunities, effect on security value, meeting expectation from market analyst, debt covenant, stock dividend disbursement by the firms and industry's common practices are proved to be the least important part while deciding payout decisions. The association between the corporate governance in the form of presence of outside directors in the managing body of the corporations and dividend policy has been established by R. La Porta et al. (2000). The study used both 'Tobit and Logit models' to analyze the dividend pattern of almost four hundred manufacturing firms listed London stock exchange to identify the factors of the payout strategy and the potential elements that might impact the possibility of dividend disbursement. It was revealed that dividend disbursement is negatively correlated with the number of nonexecutives (outside) directors in the BOD. The findings recommend that companies disburse smaller dividends when the number of outside directors is more in number in the Board. This finding is coherent with the "substitution hypothesis", which tells that corporations having inferior corporate governance sustain in the market through high payout policy. C. Boţoc and
M. Pirtea (2014) employing a databank of more than two thousand firms from sixteen nations through the time period between 2003 to 2011, exhibited that 'liquidity' and 'current asset management' affect payout policy Precisely, when shareholders protection is given more importance, the liquidity is less significant in enlightening dividend pattern, and when shareholders protection is modest, liquidity seems to be more imperative.

\section{Methodology}

\section{Sample}

The study has considered only firms/corporations from manufacturing sector listed in Dhaka stock Exchange (DSE) before 2010. The total population was 117 firms from which 86 firms were considered to be the sample by using the following sample size determination formula;

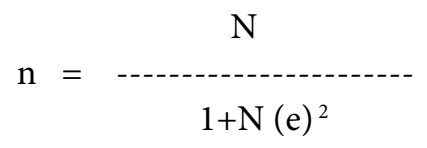

Where, $\mathrm{n}=$ Sample size, $\mathrm{N}=$ Population size, $\mathrm{e}=$ level of precision

Source: E. Slovin (1960).

The study covered the time frame of 20 years covering 1994 to 2013 . The research is characterized as an analytical one based on secondary source. Secondary data is acquired from publicly available annual reports of the sample firms, DSE website and monthly reviews. Data collection is performed through stratified random sampling technique. 


\section{Primary data source}

\section{Survey Instruments}

This study is developed on a practical observation of 86 publicly enlisted corporations from the DSE with an aim of recognize the payout strategies in practices. The primary information has been composed by applying the well thought-out questionnaire holding eight acknowledgment stand on the five-point Likert scale (Allen, Seaman, 2007) in which numerical representations are strongly agree (2), Agree (1), Indifferent/neutral (0), Disagree (-1) and strongly disagree $(-2)$. The respondents comprised of chief financial officer (CFO) and Managing director, Chairman, Board of directors of each sample corporations through post mail, email and personal appointments. Respondents were requested to point out the level of accord on question regarding their corporation's payout strategy. Additionally, eight multiple choice questions are also sent to the respondents. The questionnaire has been prepared based on the prior dividend policy literature (Baker, Powell, 2000; Brav et al., 2005; Baker et al., 1985).

\section{Parametric and non-parametric Test}

Researchers have applied one-sample t-test to establish whether the standard average response for each of the eight determinants relating to payout strategy deviate considerably from 0 (neutral). This investigation pursue the similar statistical procedure applied by H. K. Baker and G. E. Powell (2000) and A. Brav et al. (2005). The non-parametric test (Chi-square test) was also applied following the prior study of R. B. Edelman and G. E. Farrelly (1983) determining dividend policy.

\section{Analysis and Interpretations: Manufacturing Sectors}

\section{Sector-Wise Performance of dividend and dividend-related issues}

Table 1 exhibits that the mean dividend disbursement ratio (DPR) of engineering sector, cement \& jute, miscellaneous sector, pharmaceutical \& chemical sector, ceramic, textile, food, fuel \& power, are $54.49 \%$, $34.52 \%$, 63.2\%, 46.98\%, 53.14\%, 43.98\%, $40.6 \%$ and $37.76 \%$ correspondingly. Which

Table 1. Dividend performance of different sectors

\begin{tabular}{|c|c|c|c|c|c|}
\hline Sectors & DPR & DPS & EPS & DY & MPS \\
\hline Engineering & 54.49 & 24.63 & 33.85 & 3.19 & 884.1 \\
\hline Cement \& Jute & 34.52 & 9.066 & 8.8 & 2.177 & 520.2 \\
\hline Ceramic & 53.142 & 13.328 & 22.4682 & 3.44 & 560.26 \\
\hline Food & 40.6 & 25.05 & 3.03 & 3.38 & 678.28 \\
\hline Fuel \& power & 37.76 & 32.47 & 64.70 & 13.04 & 1217 \\
\hline Miscellaneous & 63.2 & 41.11 & 75.54 & 3.24 & 1529 \\
\hline Pharmaceutical \& Chemical & 46.98 & 36.63 & 79.16 & 3.03 & 1559 \\
\hline Textile & 43.98 & 12.02 & 14.74 & 3.72 & 387.9 \\
\hline
\end{tabular}

Source: the authors' calculation. 
exposed that miscellaneous, engineering, chemical \& pharmaceutical sectors have got superior DPR whereas the food and cement, jute sector experience the lesser DPR.

In Table 1, it is seen that the average dividend per share of miscellaneous sector, engineering sector, pharmaceutical \& chemical sector, ceramic, textile, food, fuel\& power, Cement \& jute are 41.11, $36.63,13.32,12.02,25.05,32.47,9.06$ percent respectively which reveal that miscellaneous, engineering sector, chemical\& pharmaceutical, fuel \& power sectors have the better DPS while the textile sector, ceramic cement, jute sector have the lower DPS.

The mean earnings per share (EPS) of engineering sector, cement sector, jute sector, ceramic sector, food sector, fuel \& power, miscellaneous, pharmaceutical \& power, textile is $33.85 \%, 8.8 \%, 22.46 \%$, $3.03 \%, 64.7 \%, 75.54 \%, 79.14 \%$ and $14.74 \%$ percent respectively. It pointed out that the pharmaceutical \& chemical, miscellaneous, fuel \& power, engineering sectors have superior EPS and food, jute, cement, textile have lower EPS compared to other sectors. The mean dividend yields are almost identical in all sectors apart from the fuel and power sector.

Lastly, it can be said that the Dividend Payout Ratio, Dividend Per Share, Earnings per share and Dividend yield of the miscellaneous sector, engineering sector, fuel \& power sector, pharmaceutical \& chemicals sector are the better performing industries whereas textile sector, cement, jute and food have the inferior picture and the mean MPS of the earlier sectors are more than that of the average MPS of later industries. So, it can be concluded that MPS is positively correlated to dividend payout strategy.

\section{Dividend payment of different categories}

Table 2 exhibits the relationship involving the listing category of the firms in DSE and determinants of dividend i.e., DPR, DPS, EPS, DY. It shows 'A' category listed firm's DPR, DPS, EPS, DY are respectively 49.63\%, 32.43\%, 58.08\%, 3.3\% whilst ' $Z$ ' category listed firms experience $35.35 \%$ $3.26 \%,-22.44 \%$ and $2.29 \%$ of DPR, DPS, EPS, DY respectively. It concludes that firms under category 'A' superior performance in dividend disbursement compared to the ' $Z$ ' category companies which are rather obvious.

\section{Dividend nature of the different size of the companies}

In Table 3, it is found that the DPS of Large, medium, small size firm are 53.37,

\section{Table 2. Dividend performance of different categories}

\begin{tabular}{|c|c|c|c|c|c|}
\hline Category & DPR & DPS & EPS & DY & MPS \\
\hline A & 49.6321 & 32.4314 & 58.0849 & 3.3 & 1165.38 \\
\hline B & 49.23258 & 8.300459 & 9.175094 & 13.37 & 329.85 \\
\hline Z & 35.35478 & 3.267773 & -22.4487 & 2.29 & 243.40 \\
\hline
\end{tabular}


Table 3. Dividend performance of different size of the firms

\begin{tabular}{|c|c|c|c|c|c|}
\hline Size & DPR & DPS & EPS & DY & MPS \\
\hline Large Size & 29.62 & 53.37 & 100.5 & 2.423 & 1899 \\
\hline Medium Size & 46.8014 & 28.6093 & 48.5317 & 2.77826 & 1078 \\
\hline Small Size & 54.18264 & 11.24284 & 7.843565 & 3.606971 & 467 \\
\hline
\end{tabular}

Source: the authors' calculation.

28.60, and 11.24 respectively. The DPR of large, medium small size firm is 29.62 , 46.80 , and 54.18 respectively. There has been a reverse relationship exhibited between DPR and DPS in case of big corporation proving that big firms are giving more stock dividend than cash dividend compared to smaller firms. The EPS of the large firm are 100.5, while the EPS of the small firms are only 7.84. The large firm's average MPS (1899) significantly larger than that of smaller firms (467).

\section{Dividend payment nature of different age of the companies}

Table 4 reveals the DPR of the firms in association the age of the listed firms. Earlier listed firms Dividend disbursement rate is more than the newly listed firms (i.e., 1976-80: 55.67\%, 1980-85: 56.98\%, 2000-05: 26.54\%, 2005-10: 31.04\%). It has been also figured out that the DPR of the firms listed before FY 2000 are more than that of the firms listed after FY2000. Similar relation can also be established between DY and firms age.

\section{Dividend and leverage}

It is exhibited from the table- 5 that the DPR of moderately leveraged firms are maximum (60.29\%) compared to high and low leveraged firms however, the MPS (1390.24) and EPS (69.81\%) of the low leveraged firms are highest compared to moderate and highly leveraged firms.

\section{Dividend and Risk}

Table 6 shows that the low risk firm's DPR, DPS, EPS, DY, MPS are $52.49 \%$, 38.73\%, 69.34\%, 3.6\%, MPS 1219.77 respectively,

Table 4. Dividend performance of different age of the firms

\begin{tabular}{|c|c|c|c|c|c|}
\hline Year & DPR & DPS & DY & EPS & MPS \\
\hline $1976-80$ & 55.67009 & 69.54433 & 3.77142 & 127.6553 & 2492.25 \\
\hline $1980-85$ & 56.98959 & 25.65987 & 2.605086 & 37.46309 & 1092.12 \\
\hline $1985-90$ & 51.7458 & 18.9972 & 3.67742 & 23.3972 & 695.72 \\
\hline $1990-95$ & 48.59985 & 20.16004 & 3.605316 & 41.57735 & 744.47 \\
\hline $1995-00$ & 57.36222 & 7.637858 & 9.202072 & 9.09 & 238.95 \\
\hline $2000-05$ & 26.54954 & 12.59411 & 2.211676 & 12.10936 & 750.06 \\
\hline $2005-10$ & 31.04485 & 35.54902 & 1.996858 & 65.53363 & 1189.36 \\
\hline
\end{tabular}

Source: the authors' calculation. 
Table 5. Leverage and dividend performance

\begin{tabular}{|c|c|c|c|c|c|}
\hline Leverage & DPR & DPS & EPS & DY & MPS \\
\hline Extremely High leveraged firm & 40.11723 & 16.7612 & 17.0681 & 2.17 & 721.38 \\
\hline High leveraged firm & 46.0569 & 21.939 & 37.0025 & 9.48 & 831.82 \\
\hline Medium leveraged firm & 60.2978 & 13.55498 & 22.19297 & 4.01 & 452.277 \\
\hline Low leveraged firm & 54.3666 & 44.0706 & 69.0424 & 4.13 & 1203.21 \\
\hline Extremely low leveraged firm & 48.54143 & 31.17432 & 69.81731 & 2.66 & 1390.24 \\
\hline
\end{tabular}

Source: the authors' calculation.

Table 6. Risk and dividend performance of different firms

\begin{tabular}{|c|c|c|c|c|c|}
\hline Risk & DPR & DPS & EPS & DY & MPS \\
\hline High-risk firm & 43.79546 & 9.47941 & -1.49453 & 3.12 & 449.08 \\
\hline Medium risk firm & 41.98837 & 18.25883 & 29.43669 & 5.24 & 880.17 \\
\hline Low-risk firm & 52.49349 & 38.73274 & 69.34622 & 3.6 & 1219.77 \\
\hline
\end{tabular}

Source: the authors' calculation.

Table 7. Ownership and dividend performance of different firms

\begin{tabular}{|c|c|c|c|c|c|}
\hline Majority Shareholdings & DPR & DPS & EPS & DY & MPS \\
\hline Sponsor (50\% and above) & 46.73 & 26.95 & 41.62 & 2.77 & 1081 \\
\hline Individual (40\% and above) & 54.68 & 15.10 & 20.58 & 7.26 & 1036.67 \\
\hline The institution (40\% and above) & 43.76254 & 26.84077 & 61.0423 & 3.53 & 521.74 \\
\hline
\end{tabular}

Source: the authors' calculation.

whilst the high-risk firm's DPR, DPS, EPS, DY, MPS are $43.79 \%, 9.47 \%,-1.49 \%$, $3.12 \%$, MPS 449.08 respectively. So, it can be concluded that the high risky firm's dividend and earning performance are not as satisfactory as compared to low and moderately risky firms.

\section{Dividend and ownership}

Table 7 reveals the association between shareholding position and dividend per- formance of firms. The DPR and DY of individual ownership (40\% and above) are $54.68 \%$ and $7.26 \%$ which is more than those of other two positions however, the DPS and EPS of individual ownership (40\% and above) are $15.10 \%$ and $20.58 \%$ consecutively which are lower than those of other positions. The sponsor ownership (50\% and above) and institutional ownership's (40\% and above) are quite similar in case of several dividend determinants and market performance. 


\section{Dividend and PE}

Table 8 demonstrates that the class of $\mathrm{PE}$ ratio in between 10-15 is the best class in case of dividend and other market-related determinants (DPR: $53.51 \%$, DPS: 50.60\%, EPS: $65.89 \%, 4.19 \%$, MPS: 1090.49). The exceedingly lower class (0-5) indicates the worst position of dividend-related performance (DPR: 7.16\%, DPS: 3.5\%, EPS: -53.34\%, DY: 2.13, MPS: 351.42).

\section{Dividend and its payment trend}

In Table 9, one finds that DPR, DPS, EPS, DY, MPS of the consistant dividend paying firms are $49.46 \%, 32.17 \%, 58.33 \%$ $3.5 \%$ and MPS 1128.27 respectively, whilst DPR, DPS, EPS, DY and MPS of irregular dividend paid firms are 40.87, $6.58,-9.46,2.62$ and MPS 376.28 respectively. This exhibits the significant dissimi- larity involving the consistantly paying and inconsistant dividend paying firms. The market performance determinants of regular dividend paying firms are considerably better than those of irregular dividend paying firms.

\section{Dividend practices: survey on the manufacturing sector}

Finally, Table 10 reflects the survey results about the executive's opinion regarding the dividend strategy. The survey result exhibited that the most of the investors have a preference for cash dividend because of liquidity preference $(65.11 \%)$ which is consistent with the findings of G. H. Partington (1989). Around 32.66\% of investors prefer stock dividend. The survey also depicts that, corporation itself also like to disburse cash dividend to investors. Around $41.86 \%$ of the firms

Table 8. PE and dividend performance of different firms

\begin{tabular}{|c|c|c|c|c|c|}
\hline Class & DPR & DPS & EPS & DY & MPS \\
\hline $20+$ & 49.6616 & 18.7843 & 29.8208 & 4.7 & 817.07 \\
\hline $15-20$ & 46.65545 & 47.22213 & 95.53292 & 3.66 & 1469.84 \\
\hline $10-15$ & 53.5115 & 50.6015 & 65.89914 & 4.19 & 1090.49 \\
\hline $5-10$ & 42.89387 & 8.531176 & -1.72206 & 5.92 & 162.53 \\
\hline $0-5$ & 7.166318 & 3.580556 & -53.344 & 2.13 & 351.42 \\
\hline
\end{tabular}

Source: the authors' calculation.

Table 9. Dividend and its payment trend

\begin{tabular}{|c|c|c|c|c|c|}
\hline Pattern & DPR & DPS & EPS & DY & MPS \\
\hline Regular & 49.46618 & 32.1759 & 58.33337 & 3.5 & 1128.27 \\
\hline Irregular & 40.87202 & 6.583771 & -9.46775 & 2.62 & 376.28 \\
\hline
\end{tabular}

Source: the authors' calculation. 
like to pay cash dividend while $20.93 \%$ would prefer to give stock dividend. The rest $32.55 \%$ of the firms would prefer both cash and stock dividend. The study findings are quite consistent with the findings of several prior studies (Baker, Mukherjee,

Table 10. Survey results of dividend practices

\begin{tabular}{|c|c|c|}
\hline \multirow{5}{*}{$\begin{array}{l}\text { Shareholders' preference for the } \\
\text { form of a dividend }\end{array}$} & Issues & Percentage of Preference \\
\hline & Cash dividend & 65.11 \\
\hline & Stock dividend & 32.66 \\
\hline & Right Issue & 0 \\
\hline & Stock repurchase & 2.23 \\
\hline \multirow{5}{*}{$\begin{array}{c}\text { Companies' preference for forms } \\
\text { of dividend }\end{array}$} & Cash dividend & 41.86 \\
\hline & Stock dividend & 20.93 \\
\hline & Cash and Stock & 32.55 \\
\hline & Stock repurchase & 0 \\
\hline & No preference & 5.81 \\
\hline \multirow{5}{*}{$\begin{array}{l}\text { Reasons for companies' prefer- } \\
\text { ence in choosing the form of a } \\
\text { dividend }\end{array}$} & Easy to implement & 20.93 \\
\hline & More flexible & 12.79 \\
\hline & Maintaining consistency & 19.76 \\
\hline & $\begin{array}{l}\text { Majority of shareholders' } \\
\text { expectation }\end{array}$ & 41.6 \\
\hline & Other & 4.64 \\
\hline \multirow[t]{3}{*}{ Dividend payment patterns } & Regular & 68.6 \\
\hline & Irregular & 27.9 \\
\hline & No dividend payment & 2.32 \\
\hline \multirow[t]{4}{*}{ Dividend payment policies } & Stable payout ratio & 54.65 \\
\hline & Constant DPS & 25.58 \\
\hline & Regular plus extra dividend & 11.62 \\
\hline & Residual dividend policy & 6.9 \\
\hline \multirow[t]{3}{*}{ Dividend payment trend } & Increasing trend & 61.62 \\
\hline & Decreasing trend & 11.62 \\
\hline & Unchanged & 24.41 \\
\hline \multirow{5}{*}{$\begin{array}{l}\text { Manager's target for dividend } \\
\text { decision }\end{array}$} & Amount of dividend & 12.79 \\
\hline & Growth in dividend & 31.39 \\
\hline & Dividend Yield & 10.46 \\
\hline & Dividend payout ratio & 24.41 \\
\hline & No target at all & 22.09 \\
\hline \multirow[t]{2}{*}{ Research for dividend preference } & Yes & 24.41 \\
\hline & No & 74.41 \\
\hline
\end{tabular}

Source: the authors' calculation based on the survey findings. 
Paskelian, 2006; Kania, 2005). Moreover, it is noticed from the survey findings that supplementary motives for preferring the kind of the dividend are simple to execute (20.93\%) and sustain regularity (19.76\%).

The results reveal that most of the companies give dividends consistently $(68.60 \%)$, whereas the rest $27.90 \%$ of firms experience inconsistency in paying dividends. Only $2.32 \%$ of firms failed to pay any dividend. Additionally, 54.65\% of firms choose the regular dividend payout strategy. The firms' additional payout strategies are stable DPS (25.58\%), constant plus additional dividend (11.62\%), and residual payout strategy $(6.9 \%)$. In case of the pattern of dividend disbursement it exhibits that $61.62 \%$ of the firms' dividend payout rate has increased while $11.61 \%$ of firms experienced negative growth and $6.9 \%$ corporation's dividend rate remain unchanged. The investigation found that maximum firms strive for the rise in dividend payout (31.39\%) and DPR (24.41\%) however a significant number of corporations have no goal at all $(22.09 \%)$. merely $24.41 \%$ of firms carried out research regarding the dividend choice of the investors.

\section{Company's views about the dividend policies: survey on nonfinancial sectors}

As it is seen in Table 11, most of the survey statements proved to be significant apart from the statement number seven. Statement six which conveys the intention to have constant dividend stream has resulted maximum average value of 1.51 and holds $91.85 \%$ of responses from respondents on the agree and strongly agree' position. This response is statistically proven to be significant by applying t-test and chi-square test. It specifies that the firms attempt to sustain the efficient payout policy throughout the year evade lessening the dividend disbursement. Almost $83 \%$ of the firms have strongly positioned on the statement eight that they tried to comply with the investors expectation while considering dividend strategy which is also found to be statistically noteworthy. So, the firms decide on their payout choice by evaluating the maximum investors dividend related expectation. The statement seven higher dividends act as a representation of firms better performance' is not statistically noteworthy which signifies that the firms don't distribute dividend to exhibit the better performance of the firms compared to competing firms. Almost $83 \%$ of the surveyed firms are strongly settled themselves on 'agree and strongly agree' position in case of statement no. eight which state that payout strategy act as the factor of increasing the firm's market value. which is proven to be statistically important. Thus, the firms create and establish their payout decision with a view to boosting the market value of the firms while considering the majority investors expectation.

\section{Conclusion}

This study intended to illustrate the dividend payout scenario of the publicly listed manufacturing firms listed in Dhaka Stock Exchange (DSE). The current study is developed on the basis of an experiential study on a sample of 86 listed manufacturing corporations from DSE with the 
Table 11. Company's view about the dividend policies



Source: the authors' calculation.

purpose of recognizing the payout policy exercise. The sample data has been accumulated through the primary way ap- plying an ordered questionnaire enclosing eight opinion-based positions on the five-point Likert scale. The researchers 
have applied one-sample t-test to ascertain whether the average value associated to each of the eight aspects linking payout strategy fluctuate considerably from Zero (Neutral). This study applied the statistical model used by earlier prominent studies carried by H. K. Baker and G. E. Powell (2000) and A. Brav et al. (2005). Moreover, the Chi-square test is also used in consistent with the study of R. B. Edelman and G. E. Farrelly (1983). The study uncovered that within the manufacturing segment, the miscellaneous sector offers the maximum disbursement. The Dividend per Share, Earning per Share, Market Price per Share of the bigger firms are superior than those of smaller and medium-sized corporations. The dividend disbursement rates of the mature corporations are more than that of the newly listed corporations. The maximum dividend disbursement is experienced in moderately leveraged corporations, smaller risky corporations and moderate Price earning ratio's corporations. The survey outcome shows that both investors and corporations like the cash dividend more because of the investor's short-term cash flow expectation. Maximum firms disburse cash dividend with a constant payout rate. Most of the firms pursue a growing pattern in dividend disbursement however there are very few reasonable studies to rationalize the investors' inclination. The executives/ managers, shareholders, and other stakeholders could use these research findings for taking investment, financing and dividend decision.

\section{References}

1. Abor, J., Bokpin, G. A. (2010). Investment Opportunities, Corporate Finance, and Dividend Payout Policy: Evidence from Emerging Markets // Studies in Economics and Finance. Vol. 27(3), pp. 180-194. doi: https:// doi.org/10.1108/10867371011060018.

2. Aggarwal, R., Kyaw, N. A. (2010). Capital Structure, Dividend Policy, and Multinationality: Theory Versus Empirical Evidence // International Review of Financial Analysis. Vol. 19(2), pp. 140-150. doi: https:// doi.org/10.1016/j.irfa.2010.01.001.

3. Aivazian, V., Booth, L., Cleary, S. (2001). Do Firms in Emerging Markets Follow Different Dividend Policies From Those in the US: Evidence From Firms in Eight Emerging Countries // Journal of Financial Research. Vol. 26(3), pp. 175-188.

4. Aivazian, V., Booth, L., Cleary, S. (2003). Do Emerging Market Firms Follow Different Dividend Policies from US Firms? // Journal of Financial Research. Vol. 26(3), pp. 371-387. doi: https://doi.org/10.1111/1475-6803.00064.

5. Al-Twaijry, A. A. (2007). Dividend Policy and Payout Ratio: Evidence from the Kuala Lumpur Stock Exchange // The Journal of Risk
Finance. Vol. 8(4), pp. 349-363. doi: https://doi. org/10.1108/15265940710777306.

6. Allen, I. E., Seaman, C. A. (2007). Likert Scales and Data Analyses // Quality Progress. Vol. 40(7), pp. 64-65.

7. Asquith, P., Mullins, D. W. (1983). The Impact of Initiating Dividend Payments on Shareholders' Wealth // Journal of Business. Vol. 56(1), pp. 77-96. doi: https://doi.org/10.1086/296187.

8. Baker, H. K., Farrelly, G. E., Edelman, R. B. (1985). A Survey of Management Views on Dividend Policy // Financial Management. Vol. 14, No. 3, pp. 78-84.

9. Baker, H. K., Mukherjee, T. K., Paskelian, O. G. (2006). How Norwegian Managers View Dividend Policy // Global Finance Journal. Vol. 17(1), pp. 155-176.

10. Baker, H. K., Powell, G. E. (2000). Determinants of Corporate Dividend Policy: A Survey of NYSE Firms // Financial Practice and Education. Vol. 10, pp. 29-40.

11. Baker, H. K., Powell, G. E., Veit, E. T. (2002). Revisiting the Dividend Puzzle: Do all of the Pieces Now Fit? // Review of Financial Economics. Vol. 11(4), pp. 241-261. 
12. Baker, H. K., Smith, D. M. (2006). In Search of a Residual Dividend Policy // Review of Financial Economics. Vol. 15(1), pp. 1-18.

13. Baker, H. K., Weigand, R. (2015). Corporate Dividend Policy Revisited // Managerial Finance. Vol. 41(2), pp. 126-144. doi: https:// doi.org/10.1108/mf-03-2014-0077.

14. Ball, R., Brown, P., Finn, F. J., Officer, R. (1979). Dividends and the Value of the Firm: Evidence from the Australian Equity Market // Australian Journal of Management. Vol. 4(1), pp. 13-26.

15. Bernhardt, D., Douglas, A., Robertson, F. (2005). Testing Dividend Signaling Models // Journal of Empirical Finance. Vol. 12(1), pp. 77-98.

16. Bhat, R., Pandey, I. (1994). Dividend Decision: A Study of Managers' Perceptions // Decision, Vol. 21(1), pp. 67-86.

17. Bhattacharyya, N. (2007). Dividend Policy: A Review // Managerial Finance. Vol. 33(1), pp. 4-13. doi: https://doi. org/10.1108/03074350710715773.

18. Black, F., Scholes, M. (1973). The Pricing of Options and Corporate Liabilities // Journal of Political Economy. Vol. 81(3), pp. 637-654.

19. Boţoc, C., Pirtea, M. (2014). Dividend payoutPolicy Drivers: Evidence from Emerging Countries // Emerging Markets Finance and Trade. Vol. 50, Issue sup4, 95-112. doi: https:// doi.org/10.2753/ree1540-496x5004s407

20. Brav, A., Graham, J. R., Harvey, C. R., Michaely, R. (2005). Payout Policy in the 21st Century // Journal of Financial Economics. Vol. 77(3), pp. 483-527.

21. Collins, M. C., Saxena, A. K., Wansley, J. W. (1996). The Role of Insiders and Dividend Policy: A Comparison of Regulated and Unregulated Firms // Journal of Financial and Strategic Decisions. Vol. 9(2), pp. 1-9.

22. DeAngelo, H., DeAngelo, L. (2006). The Irrelevance of the MM Dividend Irrelevance Theorem // Journal of Financial Economics. Vol. 79(2), pp. 293-315.

23. Denis, D. J., Osobov, I. (2008). Why do Firms Pay Dividends? International Evidence on the Determinants of Dividend Policy // Journal of Financial Economics. Vol. 89(1), pp. 62-82.

24. Dhameja, N. L. (1976). Corporate Dividend Behaviour with Special Emphasis on Growth and Controlled Companies.

25. Edelman, R. B., Farrelly, G. E. (1983). Analyzing Dividend Policy: A Questionnaire Survey.
26. Fama, E. F., Babiak, H. (1968). Dividend Policy: An Empirical Analysis // Journal of the American Statistical Association. Vol. 63(324), pp. 1132-1161.

27. Fama, E. F., French, K. R. (2002). Testing Trade-off and Pecking Order Predictions about Dividends and Debt // The Review of Financial Studies. Vol. 15(1), pp. 1-33.

28. Frank, M. Z., Goyal, V. K. (2003). Testing the Pecking Order Theory of Capital Structure // Journal of Financial Economics. Vol. 67(2), pp. 217-248.

29. Frankfurter, G. M., Lane, W. R. (1992). The Rationality of Dividends // International Review of Financial Analysis. Vol. 1(2), pp. 115-129.

30. Frankfurter, G. M., Wood Jr, B. G. (2002). Dividend Policy Theories and Their Empirical Tests // International Review of Financial Analysis. Vol. 11(2), pp. 111-138.

31. Glen, J. D., Karmokolias, Y., Miller, R. R., Shah, S. (1995). Dividend Policy and Behavior in Emerging Markets: To Pay or Not To Pay. - The World Bank.

32. Graham, J. R., Kumar, A. (2006). Do Dividend Clienteles Exist? Evidence on Dividend Preferences of Retail Investors // The Journal of Finance. Vol. 61(3), pp. 1305-1336.

33. Gugler, K., Yurtoglu, B. B. (2003). Corporate Governance and Dividend Pay-Out Policy in Germany // European Economic Review. Vol. 47(4), pp. 731-758.

34. Hashemijoo, M., Mahdavi-Ardekani, A., Younesi, N. (2012). The Impact of Dividend Policy on Share Price Volatility in the Malaysian Stock Market // Journal of Business Studies Quarterly. Vol. 4(1).

35. Ho, H. (2003). Dividend Policies in Australia and Japan // International Advances in Economic Research. Vol. 9(2), pp. 91-100.

36. Hussainey, K., Oscar Mgbame, C., ChijokeMgbame, A. M. (2011). Dividend Policy and Share Price Volatility: UK Evidence // The Journal of risk finance. Vol. 12(1), pp. 57-68.

37. Jensen, M. C. (1986). Agency Costs of Free Cash Flow, Corporate Finance, and Takeovers. The American Economic Review. Vol. 76(2), pp. 323-329.

38. Kania, S., Bacon, F. (2005). What Factors Motivate the Corporate Dividend Decision // American Society of Business and Behavioral Sciences E-Journal. Vol. 1(1), pp. 97-107. 
39. Kania, S. L. (2005). What Factors Motivate the Corporate Dividend Decision? Theses, Dissertations \& Honors Papers, p.195.

40. Kumar, J. (2003). Ownership Structure and Dividend Pay-Out in India: Working Paper. Indira Gandhi Institute of Development Research.

41. La Porta, R., Lopez-de-Silanes, F., Shleifer, A., Vishny, R. W. (2000). Agency Problems and Dividend Policies Around the World // The Journal of Finance. Vol. 55(1), pp. 1-33.

42. Lang, L. H., Litzenberger, R. H. (1989). Dividend Announcements: Cash Flow Signalling vs. Free Cash Flow Hypothesis? // Journal of financial economics. Vol. 24(1), pp. 181-191.

43. Lease, R. C., John, K., Kalay, A., Loewenstein, U., Sarig, O. H. (1999). Dividend Policy: Its Impact on Firm Value // OUP Catalogue. Oxford University Press.

44. Lintner, J. (1956). Distribution of Incomes of Corporations Among Dividends, Retained Earnings, and Taxes // The American Economic Review. Vol. 46(2), pp. 97-113.

45. Lintner, J. (1962). Dividends, Earnings, Leverage, Stock Prices and the Supply of Capital to Corporations // The Review of Economics and Statistics. Vol. 44, pp. 243-269. doi: http:// dx.doi.org/10.2307/1927792

46. Miller, M., Modigliani, F. (1961). Dividend Policy, Growth, and the Valuation of Shares.

47. Mohanty, P. (1999). Dividend and Bonus Policies of Indian Companies: An Analysis // Vikalpa. Vol. 24(4), pp. 35-42.

48. Naeem, S., Nasr, M. (2007). Dividend Policy of Pakistani Firms: Trends and Determinants // International Review of Business Research Papers. Vol. 3(3), pp. 242-254.

49. Nizar Al-Malkawi, H.-A. (2007). Determinants of Corporate Dividend Policy in Jordan: An Application of the Tobit Model // Journal of Economic and Administrative Sciences. Vol. 23(2), pp. 44-70.
50. Partington, G. H. (1989). Variables Influencing Dividend Policy in Australia: Survey Results // Journal of Business Finance \& Accounting. Vol. 16(2), pp. 165-182.

51. Parua, A., Gupta, A. (2009). Dividend Histories and Determinants in Selected Indian Companies: A Study During 1993-'94 to 2004- '05 // Australasian Accounting Business \& Finance Journal, Vol. 3(4), 45A.

52. Pettit, R. R. (1977). Taxes, Transactions Costs and the Clientele Effect of Dividends // Journal of financial Economics, Vol. 5(3), pp. 419-436.

53. Richardson, G., Sefcik, S. E., Thompson, R. (1986). A Test of Dividend Irrelevance Using Volume Reactions to a Change in Dividend Policy // Journal of Financial Economics, Vol. 17(2), pp. 313-333.

54. Ross, S. A. (2009). Neoclassical Finance. Princeton University Press.

55. Rozeff, M. S. (1982). Growth, Beta and Agency Costs as Determinants of Dividend Payout Ratios // Journal of Financial Research, Vol. 5(3), pp. 249-259.

56. Shefrin, H. M., Statman, M. (1984). Explaining Investor Preference for Cash Dividends // Journal of Financial Economics. Vol. 13(2), pp. 253-282.

57. Slovin, E. (1960). Slovin's Formula for Sampling Technique.

58. Smith, D. M. (2009). Residual Dividend Policy / In Dividends and Dividend Policy. - John Wiley \& Sons: Hoboken, NJ, pp. 115-126.

59. Smith Jr, C. W., Watts, R. L. (1992). The Investment Opportunity Set and Corporate Financing, Dividend, and Compensation Policies // Journal of Financial Economics. Vol. 32(3), pp. 263-292.

The paper submitted: March 10, 2019 Prepared for publication: August 5, 2019 
Mohammad Shahidul ISLAM, ATM ADNAN

DIVIDENDỤ PRAKTIKOS LISTINGUOJAMOSE İMONĖSE: BANGLADEŠO GAMYBOS SEKTORIAUS TYRIMAS

\section{S a n t r a u k}

Finansinio raštingumo srities ekspertai ivvairiais būdais vertina įmonių dividendų elgesį. Siekiant ištirti Bangladešo gamybos sektoriaus įmonių dividendų praktikas, tyrime nagrinejjami antriniai duomenys ir dividendų politikos formuotojų požiūriai, apimantys skirtingus dividendų praktikų aspektus. Tyrime naudoti šie metodai: parametriniai, neparametriniai, aprašomoji statistika. Tyrimas atskleidè, kad gamybos sektoriuje ịvairių produktų gamybos segmento įmonès išmokèjo didžiausius dividendus. Nustatyta, kad didžiųjų i̇monių dividendų pelningumo koeficiento (DPS), pelno vienai akcijai (EPS) ir ribinio polinkio taupyti (MPS) rodikliai yra geresni, palyginti su mažų ir vidutinių įmonių rodikliais.
Taip pat senesnių įmonių dividendu išmokèjimai yra didesni nei naujai listinguojamų įmonių. Didžiausias dividendų pelningumas nustatytas i̇monėse, kurios pasižymejo vidutiniu svertu ir vidutiniu akcijos kainos ir pelno santykio $(\mathrm{P} / \mathrm{E})$ rodikliu. Apklausos rezultatai atskleidè, kad investuotojai ir valdytojai pirmenybę teikia grynųjų pinigų dividendams dèl rinkos lūkesčių ir likvidumo preferencijos. Taip pat dauguma ịmonių moka dividendus grynais pinigais ir išlaiko stabilią dividendų normą. Tyrime pasigendama investuotojų preferencijos dividendụ modeliui pateisinimo. Tyrimas naudingas ir aktualus rinkos analitikams, investuotojams ir kitoms suinteresuotoms šalims, kurios gali gauti naudos iš tyrimo išvadų priimdamos atitinkamus sprendimus. 